\title{
Guided portfolio writing as a scaffold for reflective learning in in-service contexts: a case study ${ }^{1}$
}

\author{
Íris Susana Pires Pereira ${ }^{\mathrm{a} *}$, Maria Cristina Cristo Parente ${ }^{\mathrm{a}}$ and \\ Cristina Vieira da Silva ${ }^{\mathrm{b}}$ \\ ${ }^{a}$ Departamento de Estudos Integrados em Literacia, Didática e Supervisão, Instituto da \\ Educação, Universidade do Minho, Campus de Gualtar, 4710-057 Braga, Portugal; \\ ${ }^{b}$ Departamento de Formação de Professores, e o nome da Escola é Escola Superior de \\ Educação de Paula Frassinetti, R. Gil Vicente, 138-140, 4000-255 Porto, Portugal
}

(Received 26 February 2014; final version received 1 June 2015)

\begin{abstract}
Language is widely recognized as an inescapable mediating tool for professional learning, and with this text we want to contribute to a better understanding of the particular role that guided writing can play in in-service professional reflective learning. We analysed one pre-school teacher's written portfolio, the construction of which was guided to scaffold deep thinking about (and the transference of theory into) practice during participation in an in-service program about language education. Our case study shows that the writing process sustained robust learning about professional knowing, doing and learning itself: The teacher elaborated an integrative ethical understanding of the discussed theory, fully experienced newly informed practices and assessed her own learning by using theory to confront her previous knowledge and practices. Throughout the portfolio, the learning stance revealed by her voice varied accordingly. The study illustrates the potential of guided writing to scaffold reflective learning in in-service contexts.
\end{abstract}

Keywords: in-service learning; reflection; portfolio; writing; scaffolding

\section{Introduction}

Major principles sustain our current understanding of teachers' professional learning: Learning is centered on the learner's previous knowledge, motivations and interests (Dewey 1916); it implies having access to structured knowledge and its transference into practice (Dewey 1938; Shulman 1986; Day 1993); it involves processes of (self) assessment and monitorization (Marcos, Miguel, and Tillema 2009); and is best constructed within (and with the active engagement of) the learner's professional community, which provides the necessary social scaffolding for learning to take place (Vygotsky 1986; Lave and Wenger 1991).

Reflection, which we take as a synonym for deliberate thinking about oneself as a practitioner with the aim of improving understanding and practices (Dewey 1916, 1938; Schön 1983; Taguchi 2010), is a crucial dimension of teachers' learning experiences. Indeed, there has been a re-conceptualization of teachers from 'knowledge users and exemplary technicians' into 'conscious knowledge producers and

\footnotetext{
*Corresponding author. Email: iris@ie.uminho.pt
} 
transformers of their own practice' through reflection (Cochran-Smith and Lytle 1993; Hatton and Smith 1995; Zeichner and Liston 1996; Moon 2004; Marcos, Miguel, and Tillema 2009). Reflection is now recognized to be the most powerful driving force for self-monitored, conscious and conscientious learning and doing, empowering teachers to actively resist and transform mechanical, practical attitudes and successfully answer the demands put by an ever-changing educational world. Indeed 'reflective learning' has been characterized as teachers' specialized form of cognition (Bazerman 2009; Pereira 2014).

Language is widely recognized as an inescapable mediating tool for learning (Vygotsky 1986; Doecke and Pereira 2012), and with this text we aim to contribute to a better understanding of the particular role that guided writing can play in professional reflective learning. We present research on the role of guided written portfolios in the construction of professional reflective learning in an in-service program for pre-school teachers. We based our research on the central assumption that written language promotes reflective learning, especially when it is guided.

In Section 2, we situate our inquiry by briefly discussing guided portfolio writing as a form of scaffolding reflective learning and by problematizing its effectiveness in in-service learning contexts. In the remaining sections, a case study of the written portfolio of one in-service teacher is presented, analysed and discussed. In Section 3, we contextualize the research by presenting the in-service program in the context in which the portfolio was written and identify the case we studied. We detail the qualitative analytical procedures we followed and introduce the learning dimensions constructed by the teacher, the role played by the theory and the learner's stances to the issues under analysis. In Section 4, we present the results of the analysis, and, in Section 5, we discuss those results as illuminating the potential of guided portfolio writing in the construction of reflective learning in in-service contexts as well as central tenets of reflective learning theory. We argue that portfolio writing crossscaffolded all the learning achieved by rendering it tangible and thus monitorable for the learner herself. The limitations of the study are also highlighted. Our conclusions also include the discussion of some implications for the conceptualization of the study of exemplary cases for further increasing the understanding of scaffolding for in-service teachers.

\section{Scaffolding reflective learning through portfolio writing in in-service contexts}

Reflective learning is an important as it is a difficult endeavor for teachers to undertake (Bazerman et al. 2013), which may be taken as a sign of the importance of scaffolding it. Orland-Barak and Yinon (2007) and Korthagen and Vasalos (2005) convincingly argue about the necessity of scaffolding reflective learning in preservice contexts to overcome such difficulty. Writing is a powerful means of promoting such scaffolding (Bazerman 2009; Pereira 2014). Indeed writing has received renewed interest in the context of the acknowledgment of the cognitive role of language in reflective learning from experience.

Language is the most important mediating tool for learning from experience and for the development of cognition. The role it plays in scaffolding learning from experience is complex as it acts both socially and individually. The idea, originating in Vygotsky (1986), that people start by learning interpersonally, "talking through" tasks with another person and then internalizing that conversation as thought' 
(Bruffee 1986, 785) is a premise for this investigation; when such inner conversations become spontaneously enacted by the learners themselves while facing any practical problem, they have become able to further act and extend their learning on their own. Language is therefore the vehicle for (life-long) thinking and learning from experience (Vygotsky 1986; Wells 1999).

Writing adds to the role played by oral language by rendering thinking tangible, thus providing a means of self-monitoring for the learners themselves. In fact, by writing to ourselves we represent our experience for our own understanding and learning (Britton 1970). When we construct a written text from experience, we construct a verbal representation that is autonomous from what was lived. Through the process of creating such representation, the contents of our thinking are objectified, made specific, stable, analysable, editable and liable to be shared and validated by others (Eisner 1982). Put another way, writing about experience extends thinking, allowing thinking about thinking, and this meta-cognitive dimension of writing has a powerful heuristic force: '[t]he act of making [a representation] is not only an occasion for expressing or representing what you already know, imagine, or feel; it is also a means through which the forms of things unknown can be uncovered' (Eisner 2006, 109), opening up possibilities for rethinking what is known and for (re)constructing future experience for those who write (Marcos, Miguel, and Tillema 2009).

Speaking from the specific standpoint of pedagogical phenomenology, Van Manen's ideas about the role of writing in reflectively learning from experience are an extremely important contribution to our discussion (Van Manen 1989, 1990, 2006). He conceives of writing as the method for any kind of research that aims to make personal insights from lived experience. As he puts it, writing 'places consciousness in the position of the possibility of confronting itself, in a self-reflective relation' (Van Manen 1989, 30). He characterizes the act of writing about one's experience as a process that both 'separates us from what we know and yet unites us more closely with what we know' (28), and that intellectualizes our experience by exercising 'our ability to see (...) at the same time that it shows the limits and boundaries of our sightedness' (31). Van Manen thus highlights the potential of writing as a method of self-knowing, 'a kind of self-making or forming' (31), as well as an opportunity of directing thinking to praxis, 'a potentially more tactful action' (30), an improved experience.

Teacher education has been particularly impacted by this interest in writing due to the potential it holds for enhancing reflective learning from professional experience (Rosen 1987; Hatton and Smith 1995; Zeichner and Liston 1996; Broekman and Scott 2006; Doecke and Pereira 2012; Bazerman et al. 2013; Doecke 2013; Pereira 2014).

In this renewed epistemological understanding concerning teachers' reflective cognition and reappraisal of the role of written language in such cognitive development, new, demanding situated literacy practices have emerged in teacher education programs. Portfolio writing has become one such practice (Shulman 1998; Darling 2001; Vieira 2006; Sá-Chaves 2009). Referring specifically to pre-service teachers, Darling $(2001,111)$ defines the teacher's portfolio as a:

narrative that tells a coherent story of student teachers' learning experiences (...) and highlights thoughtful reflection on, and analysis of, those experiences. It is not simply an accumulation of pieces and products; it is an unfolding [of their] understandings about teaching and learning, and about their development as a professional. 
From this perspective, student teachers are the main audience for the meanings and theorizing they make of their practice through portfolio writing. The purpose of producing such personalized analyses of beginning situated practice is to lay the foundation of a reflective disposition and their autonomy in future action and learning. The 'learning portfolio' (Zeichner and Wray 2001) is thus assumed as a tool that supports the construction of teachers' specialized reflective cognition and practical epistemology, the development of their professional identity and belonging to their community of practice (Darling 2001).

Yet, portfolio writing has also been a matter of dispute. To start with, the definition of the teacher portfolio is not a straightforward one (Anderson and De Meulle 1998). In fact, when discussing her conception of teacher portfolios, which Darling refers to as the 'ownership' model of the portfolio, she also mentions other possibilities, namely the 'feedback' and 'accountability' models, each of which is associated with other purposes, such as the guidance of the learning process and documenting, evaluation and professional 'certifying,' respectively (Wolf and Siu-Runyan 1996). Delandshere and Arens (2003) thoroughly analysed teacher portfolios that were essentially developed for performance-based assessment in three pre-service contexts with reference to official teaching standards (with the collateral aim of serving the evaluation of teachers' education programs). They seem to conclude that portfolios are actually being developed according to a renewed technical paradigm of teaching, as they found portfolios to be a sort of storefront of selected, though theoretically unframed, constructions, evidencing a complete 'misunderstanding of what constitutes explanation of and reflection about teaching' (66). As the authors put it, 'given the stakes involved (i.e. consequences of assessment and accreditation), the performances become an end in themselves, and the learning that occurs - as a result of enacting these performances or of documenting them - is not carefully considered' (72).

'The learning portfolio' or ownership model is the focus of our discussion in this article. It has revealed itself as being difficult to accomplish, which has been used to question the effectiveness of learning through such a practice. In this respect, the need to scaffold its writing has been discussed. Some researchers have raised questions about the effectiveness of learning through such a practice, discussing, in particular, the importance of structuring portfolio writing (Korthagen and Vasalos 2005; Bazerman et al. 2013). Berril and Addison (2010) and Imhof and Picard (2009), for instance, have called our attention to contextual factors that deeply influence the effectiveness of portfolio writing in reflective learning from experience, such as the explicitness of the aims and instructions, the unambiguous understanding of the advantages and benefits of personal learning as well as personal traits of the portfolio writers (disposition to learn, openness in facing professional challenges, belief in participation and active involvement in professional learning, among others).

As we see it, portfolio writing in in-service learning contexts deserves close consideration. In-service learning has been deeply impacted by the renewed understanding of professional learning. Portugal is just another example, as reflective learning and reflective literacy practices have become core features of in-service legislation (Silva 2000). However, in-service learning contexts pose important challenges to this new learning framework. The emergence of the reflective paradigm, with the associated valuing of literacy practices such as portfolio writing, has meant a considerable challenge in learning and communicating processes for teachers who have learned their profession with reference to the technical learning paradigm, according to 
which teaching was conceived of with a narrow pragmatic focus on effectiveness, and teachers were seen as efficient appliers of other people's designed practical recipes. The new way of conceiving teaching as a reflective endeavour, of thinking oneself and of reconstructing oneself as a practitioner and of communicating that learning, is radically different from past conceptions and practices. And despite the considerable differences there are between knowledgeable and inexperienced teachers, we think in-service teachers would therefore also benefit from scaffolding for reflective learning through structured portfolio writing in order to scaffold their own reflectiveness.

In this context, the following major question came to our minds: How effective can guided portfolio writing be in scaffolding reflective learning in in-service contexts? In this paper we present the research that we carried out in order to answer this question.

\section{The study}

\subsection{Context of study}

The prompt for the case study presented in this paper was an instance of an in-service training program specifically designed to help pre-school teachers learn about language education (Pereira 2012). The political changes introduced in recent decades in Portugal with the aim of improving pre-school education made professional learning indispensable (Katz et al. 1998; OECD 2000, 2006). In fact, the need for professional in-service training amongst Portuguese pre-school teachers has been acknowledged as a way of helping 'practitioners (...) become more reflective (...) and take more responsibility for their professional development' (OECD 2000, 32). Language education has been identified as one of the underdeveloped professional dimensions among pre-school teachers (Dionísio and Pereira 2006; Vasconcelos 2006; Lopes and Fernandes 2009). The aim of the program was therefore to promote teachers' reflective learning about language education in pre-school years. The program took the form of a 'focused action-research' process, combining 'a fusion between trainer-centred input and teacher-centred action research' (Kemmis and McTaggart 1987; Elliott 1991; Day 1999; Perret 2003, 1). The intention was for the teachers to get acquainted with a carefully systematized theoretical view about language education in the pre-school years that would support their inquiries into their own language education knowledge and practices.

The program was carried out by 23 primary teachers who were developing an official in-service program for their primary teacher peers under the supervision of the first of the authors of this text (Pereira 2010). The in-service program for preschool teachers was implemented in their professional contexts, the same school centers as the primary teachers'. There, an interaction was thus established between 'quasi-peer' teachers, as their professional responsibilities and interests intersect. A collegial training relationship was created, which, together with the development of the program in the very contexts of practice, is referred to as desirable in creating teachers' learning environments (Day 1999).

The trainers imparted 10 lecture-discussion sessions (total: 25 hours), organized into three thematic learning modules, namely oral language development, language awareness and emergent literacy (Pereira 2012). The trainers received special training for (as well as the core materials to be used in) each of the sessions. Besides the group discussion dynamics, there was an individual learning component (total: 25 
hours), during which pre-school teachers were expected to inspect their own language education conceptions and practices within the educational settings in which they worked. Teachers shared their new experiences in follow-up meetings.

Portfolio writing played a special role in this contextual scaffolding. We designed it to let teachers actively construct, identify and monitor their own learning about each module, but the guidelines we offered were not equally mandatory. Before the study of each module and to get the reflective process started, the teachers were asked to analytically report one task they considered to be representative of the issue to be studied (henceforth referred to as 'preliminary reflections'). After each of the three learning modules was discussed, teachers were asked to write a synthesis of the information they had learned and to plan, analyse and critically report a practical experience (developed in their classrooms) in which they should apply that knowledge. Finally, teachers were asked to think about the contents and experiences and their usefulness in updating their practical knowledge. At this point, the suggestion was made that their preliminary reflections would be potential reference points to help them finally identify what they thought they might have learned in the meantime. In their portfolios, teachers were therefore free to recover their preliminary reflections, as they might find those pre-learning texts potentially much too revealing about themselves (Figure 1). When designing these portfolio guidelines and suggestions for portfolio writing, we assumed with Shulman (1998) that the available theory could turn the construction of the portfolio into a meaningful practice, and our intention was to scaffold teachers' conscious and systematic (re)construction of relevant professional knowledge about language education in the pre-school years (Schön 1983; Shulman 1986; Day 1993, 1999).

This in-service program was accredited. The learning process took three to five months, according to the dynamics that were negotiated at each school center. The participation was voluntary and more than 350 pre-school teachers took part in the in-service program, the majority of whom were very experienced, as is currently the norm among pre-school teachers in state schools in Portugal (Pereira 2012). The program took place in 2010 in most cases.

\subsection{Methodology: case study, issues and analytical procedure}

After portfolios were attentively read, one pre-school teacher's portfolio was selected for our analysis because it closely followed the guidelines we offered for portfolio writing, either mandatory or optional.

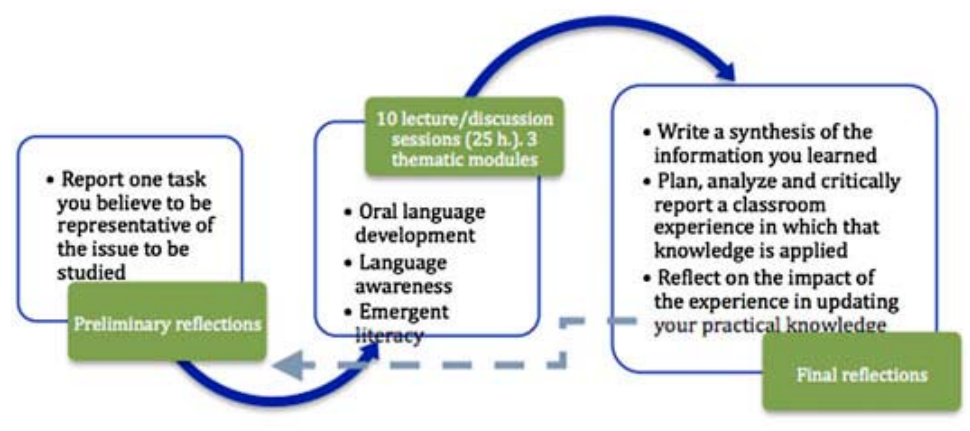

Figure 1. The portfolio writing process. 
The portfolio was organized into four parts. The first three parts were dedicated to each of the three learning modules, and were equally organized into: Section 1, Reflection on the scientific contents learned and their usefulness in updating pedagogical knowledge and practices; Section 2, Examples of tasks that were implemented: analysis and critical reflection; Section 3, The role of the pre-school teacher. Finally, there was a Conclusion, which the teacher divided up according to the following subheadings: Self-assessment. Preliminary reflections and final activities in each module: Comparative analysis. In this part, the teacher recovered and confronted, module by module, each of her preliminary reflections and each of her (newly) experimented tasks. The portfolio also struck us as being a single, coherent and cohesive text, which was not the norm among participants, the majority of whom handed in written portfolios which we can only describe as being a mere juxtaposition of discrete texts. As such, we found our guidelines operating in this case (Stake 2000), which, in some aspects, were made even more precise by the teacher herself. We found this to be an exemplary portfolio as far as meeting the formal requirements needed for our study, and we decided to focus our attention on this case believing it offered enormous potential for an in-depth understanding of the reflective learning constructed by following such guidelines.

In order to answer our research question, we focused on three issues (Stake 2000), namely kinds of reflective learning, role of theory in the learning that was constructed, and learning stance, and the following three sub-questions were thus defined:

a. What kinds of learning did this teacher reflectively construct by following the guidelines for portfolio writing?

This question is relevant because the guidelines we offered were meant to scaffold teachers' reflections into three learning domains, namely learning about knowing, learning about doing and learning about learning, which we identified as different learning domains potentially offered to teachers. We thus wanted to know the effectiveness of these guidelines in this specific case.

\section{b. What was the role of theory in the learning constructed?}

This question was asked because the whole in-service was designed to offer a systematized theoretical view of language education in pre-school years. Theoretical understanding of teacher education stresses the fundamental role played by knowledge (Shulman 1986; Day 1993). We therefore wanted to know how and whether theory had been used in the learning the teacher represented in the portfolio.

\section{c. Which learning stance did the teacher assume during such learning processes?}

This question came up due to our interest in researching the nature of the reflective voices of teachers (Pereira 2014). The learner's voice is a specific linguistic dimension of the specialized way of dealing with words that goes with reflective thinking (Pereira 2014). This is a process of looking inside oneself and at our actions, thus implying a close positioning of the learner, at the same time as also implying a detached analysis to identify learning. We assumed the learner's stance 
to be relevant to inquire into because we wanted to characterize the learner's relationship with the theory she became acquainted with and that she applied in her experimented practices. With this specific question we thus wanted to know how the teacher positioned herself in the construction of the learning dimensions into which we guided her.

Our analysis was interpretative (Miles and Huberman 1994), and we chose a categorical aggregation procedure (Stake 2000). To answer the first sub-question, each one of us started an independent analytical top-down categorization by using three macro-categories developed from the structure of the portfolio, namely learning about knowing, learning about doing and learning about learning. To answer the second sub-question, we carried out another analytical top-down categorization within each of the learning domains previously identified. The categorization was based on the theoretical themes that were studied in each module (oral language, language awareness and emergent literacy). In both cases, we identified textual stretches corresponding to the analytical categories, and triangulated them amongst ourselves for internal validation. Secondly, each one of us reread each stretch to identify the functions played by the reference to theoretical knowledge within each category, which were then independently labeled. Again, the result was triangulated, including the ultimate labeling and selecting of the most illustrative evidence for each label.

To answer the third question, we focused again within each of the learning domains, looking for the voice that promulgated the learning achieved. We assumed that the voice revealed the 'stance' or relationship with the learning achieved. In this case, no previous categories were used, and categorization emerged from the data. The result was triangulated and we chose the most illustrative evidence for each stance that we identified.

No further data was analysed for triangulation, but we consider it relevant to highlight that parallel themes emerged for each category throughout the portfolio due to its internal parallel organization, turning, as far as we can see, the internal structure of the portfolio into a source of triangulation for our findings.

\section{Findings}

The results of the analysis show robust reflective learning about knowing, doing and learning. The teacher elaborated a synthesis of the theory she learned about, thoroughly analysed new theoretically informed practices she experimented with her children, and self-assessed her learning by confronting what she had learned with her previous knowledge and practices. The results also show that the theory learned, well captured by the knowing dimension, traversed the other aspects of learning. The analysis further revealed a systematic modulation in the teacher's voice: throughout the portfolio, the learning stance revealed by her voice varied according to the learning that was constructed.

\subsection{Learning about knowing; new knowledge founding language education ethos; an impersonal voice}

In the portfolio, the teacher elaborated three syntheses of the theory she learned about on language education in pre-school years (Section 1 of each of the first three parts). These are clearly the result of her own elaborations based upon information she had access to in the sessions and on information that she further researched. This 
process is clearly illustrated in the excerpt below taken from part one, referring to oral language development in pre-school education. ${ }^{2}$ The initial ideas were discussed in the theoretical sessions, but the excerpt results from the teacher's own research:

\begin{abstract}
There is, in each human being, a genetic and a cultural dimension [in the learning of languages], they both interact in the development of children, none acts in isolation. In language learning, this interaction is especially relevant because, despite the innate predisposition to learn a language, such innate predisposition only develops if there is a socially stimulating context. The rare cases of children who have been isolated from human contact show that one only learns a language by talking to other people. There is even the assumption of the existence of a critical period for the acquisition of languages, after which it would be impossible for children (or at least it would be harder) to communicate through language. Such a critical period is the "moment in which the child's brain presents an extraordinary plasticity (...) and can mediate, without any conscious effort, the concrete development of proper neural circuits for the perfect command of one or more natural languages. (...) the critical period can extend up to around the age of seven.' (Source: www.letras.ufrj.br/clipsen/linguistic_1/texto1.doc (...). (Portfolio, Part I, section A, 2)
\end{abstract}

Throughout the other similar parts in the portfolio, she quotes some information but mostly integrates what she learned about in her own discourse.

Also of relevance is the fact that some of the discussed theory is referred to beyond the boundaries of each module, which reveals that she integrated information from one module into others as the in-service program progressed. In the following example, which comes from section A of Part III dedicated to emergent literacy, the teacher relates the learning of letters to the learning of sounds, which she discussed in Part I (oral language development), and to phonological awareness, which she discussed in Part II (language awareness). Again we come across her elaborations based on her research, as there was no discussion about the meaning of the word 'literacy' in the sessions:

There is continuity between children's oral language practices and the learning of reading and writing. (...) [L]etters (literacy comes from littera - letter) are symbols for phonemes, that is, forms that represent sounds. There is an interrelation between language sounds and letters. The child who has become aware of the sounds that exist in words has more facility for learning the written language. Oral language and writing influence each other reciprocally. (Portfolio, Part III, section A, 18)

In these sections of her portfolio, the teacher systematically uses theoretical knowledge to sustain her in her work as a language educator in the pre-school years. Put another way, she systematically refers to what she understands as the ethics of her profession in relation to each segment of knowledge on language education that she discusses:

Pre-school education has to provide [children from culturally unfavourable family contexts] adequate linguistic nurturing, in quantity and quality, and thus contribute to offering them equal opportunities. (Portfolio, Part I, section A, 4)

In pre-school, before children learn the letters of the alphabet, [they] must start with sounds. (Portfolio, Part II, section A, 13)

The pre-school teacher must interact with the children, promote interactions among them and with other people in order to promote the advance of children's emergent literacy. (Portfolio, Part III, section A, 21)

As we can observe in these excerpts, the voice involved in the enunciation of this learning is constantly heard in the third person. In these excerpts, this impersonal voice is heard when she refers to 'the pre-school,' 'pre-school education,' 'the 
child,' and 'the pre-school teacher,' but it is equally heard when she exposes knowledge, such as in 'Consciousness is being aware of something, to think of it. Language awareness is the reflection on and about language' (Portfolio, Part II, section 1, 12). This impersonal voice is a constant feature in these parts of the portfolio, in which it conveys an objective and authorized stance towards the knowledge constructed. Knowledge is the focus of the teacher's reflection in each of these sections, and she has appropriated that knowledge.

\subsection{Learning about doing; new knowledge sustaining planning and practice analysis; voices from within the classroom}

In the three initial parts of the portfolio, the teacher presents examples of practices that she experienced by applying the theory she learned about (Section 2, Examples of tasks [that were implemented]: analysis and critical reflection; Section 3, The role of the pre-school teacher). Each of these tasks is thoroughly reported: we know the details of what she did, why it was done and the analysis of what happened. Theory sustains each of these dimensions of her analytical reports.

For instance, in sections 2 and 3 of Part II (pages 14-16), the teacher names the task ('Introduction to phonological awareness: rhyme identification'), justifies the option for this task ('Taking the children's age (3 to 4 ) into consideration, an initiation activity [to phonological awareness] seemed to be more adequate'), identifies the learning objectives:

The aim was for the children to identify equal oral segments in words. By directing their attention to these oral segments (those which rhyme), children begin to be aware of the sounds in words (Portfolio, Part II, sections 2 and 3, 14-16)

and details the task itinerary:

Some drawings were presented to children on a blank page, 12 drawings with an empty square next to them. The children said, aloud and together, the names of the objects that were represented in the drawings: spinning top, violin, cat, bottle, ball, scissors, carrot, shoe, bell, lion, giraffe, coil [pião, violino, gato, garrafa, bola, tesoura / leão, sino, sapato, girafa, mola, cenoura, pairs of rhyming words in Portuguese]. Then, each should use the same colours to paint the squares corresponding to the pair of rhyming words. (Portfolio, Part II, sections 2 and 3, 14-16)

Then she deeply scrutinizes what happened. She analyses the children's performances, assessing the experimented task:

The attempt to carry out this task with the four [three-year-old] children was by and large unfruitful. It was almost a suffering experience to see these children try and do the task. [Yet] There was an exception. (...) The other eleven children did not perform alike [detailed report]. (...) Conclusion: Although the three year olds have manifested a virtual incapacity to carry out the task, there was an exception. (...) This child developed awareness of the sound segments in words that rhymed. That was the objective: To begin to be aware of the sound segments in words. One is led to conclude that, although age is an important factor, it is not absolutely determining. If that was so, there were no exceptions. Probably there are other factors ... Most of the four-year-olds had no difficulty. (Portfolio, Part II, section 2, 14-15)

In these sections of the portfolio, we listen to an expositional, analytical, and even theorizing voice: the teacher transfers theory into her practice and retells it in her own words, that is, she re-constructs for herself the authorial theory that she learned about on the basis of her own experience. Another interesting example of this 
learning movement is provided in Part III. To conclude the analysis of the data she gathered through a dialog she kept with the children a propos the reading and writing of a letter to Santa Claus, she says:

Children do relate reading and writing: they understand that one writes [something] to be read. 'One writes to read, doesn't one?,' 'to receive and write a letter to Santa Claus,' 'to read,' etc. This implies that children have a notion about what reading and writing are. These notions, which may be analysed, clarified, constitute their emergent literacy. (Portfolio, Part III, section 2, 28, original bold)

In section 3 of each of parts I, II, and III, she analyses her own role during the experimented tasks. She justifies actions and decisions she took during the task:

One cannot take means for ends. Therefore, when I realized that in some cases the means was becoming an obstacle [to the aims], I changed it for another: children who were identifying rhymes orally but were not filling the square correctly started to unite with a line the corresponding drawings (...). I considered the way children accomplished the aim. It was about identifying rhymes and not about painting correctly. (Portfolio, Part II, section 3, 16)

In this particular example, we listen to the voice of the teacher in the first person. In the sections under analysis, we also listen to the children's voices, which the teacher always analyses after transcribing:

Task: 'Talk about autumn'

In the morning, when we entered the room ... The day before, I had asked children to bring something related to autumn.

Child 1: I have a leaf (the leaf was in the transparent bag that she carried).

Teacher: Do you? Show it to us, then (Child 1 brought out the leaf and showed it). Why did you bring it to school?

Child 1: It's from the autumn!

Child 2: Teacher, I didn't brought anything from autumn. (Portfolio, Part I, section 2, page 6 , original bold)

Children were encouraged to express themselves and attention was given to what they were saying. Incorrectly pronounced words were returned to children in a correct form and integrated in a sentence

Child 2: Teacher, I didn't brought [trazi, incorrect verbal inflexion in Portuguese] anything from autumn.

Teacher: You didn't bring something from autumn [trouxeste, correct verbal inflexion in Portuguese]. That's OK, you can bring something tomorrow. (Portfolio, Part I, section 2, 8, original bolds)

In parts 2 and 3 of the portfolio, the voices that speak are situated within the classroom and tell us about what happened in there. In these parts, practice is the focus of the teacher's reflection.

\subsection{Learning about learning; theory illuminating professional learning; learner's personal voice}

The conclusion of the portfolio is totally devoted to the identification of the learning constructed. It begins by the teacher stating that 
[In here] I compare the preliminary reflections with the tasks that were carried out after each learning module in order to verify whether there is any significant difference between before and after. Thus I can assess my own learning. (Portfolio, Conclusion, 30)

The teacher again organizes the conclusion into three parts. In each, she begins by recovering her full preliminary reflections (section A). Our analysis of such pieces is revealing about the teacher's concern with thoroughly reporting practice and theoretically sustaining it: we learn that this is a constant in her professional behavior. Even more revealing is the systematic confrontation of such previous practices and assumptions, which the teacher does in section B. She analyses the preliminary reflections, compares them to the new practices she experienced and identifies the new learning or transformations that she went through by participating in the in-service program. For instance, in the preliminary reflection for the learning module on emergent literacy, the teacher reported that:

This task was reading a text. Such reading is in an emergent state and children start by associating spoken words to images. This association allows them to start to associate the same images to written words. When they put the written words to the images from the text, they already associate images for the written words. The main objective [of this task] was that children associated images to written words. (Portfolio, Conclusion, Module III, 33, our italics)

When she confronts this preliminary practice, she changes the way she refers to the task ('In the initial activity, children read (...) the images of a text' (Portfolio, Conclusion, Module III, 34, our italics), identifies some relevant dimensions of this task that she had not acknowledged before ('That eventually might help children start to learn how to read. It also allows them to interiorize some reading and writing procedures, such as its orientation: left to right, top to bottom' (Portfolio, Conclusion, Module III, 34)), and she identifies the major transformation that she went through between her preliminary reflection (and previous knowledge) and the experimented practice:

Yet the substantial difference between the first and the second tasks lies in the idea that led them. Initially I understood 'literacy' as knowing how to read and write. I had not assimilated the concept of 'emergent literacy.' To learn how to read and write is a second phase, a more advanced one, of literacy [learning]. Literacy in pre-school emergent literacy - is a set of ideas about reading and writing upon which the [formal] learning of reading and writing will be constructed. Literacy does not start by the learning of reading and writing, but by the construction of a set of ideas about reading and writing. The distinction between 'literacy' and 'emergent literacy,' as well as the importance of the latter, were learnings I constructed in this module. (Portfolio, Conclusion, Module III, 34)

The theory was used to guide the conscious revisiting of herself and the monitorization of professional transformations.

This is the part of the portfolio in which her personal voice is most clearly audible. She makes herself, as a learner, the focus of her attention. We listen to her saying 'I learned this attitude' (Portfolio, Conclusion, Module I, 31); 'I was able to realize'; 'I acquired this knowledge in the in-service program' (Portfolio, Conclusion, Module II, 33).

\section{Discussion}

The results of our case study allow us to contend that guided portfolios can be effective scaffolds in the construction of reflective learning in in-service contexts. 
The teacher constructed different kinds of learning: On language education in pre-school years, about practice and about herself as a learner. Such learning was achieved by a dynamic use of theory, which was relevant and applied to each of these learning domains. It supported the teacher's understanding of the ethics of her practice concerning language education (by allowing her to identify new essential aspects of practice), the construction of her pedagogical experience (by allowing her to analyse the effectiveness of such aspects in renewed practice) and her self-confrontation as a practitioner with extensive previous practical knowledge. In this context, theory illuminated the teacher's conscious professional growth. The learner's stances varied throughout, which we assume as a strong indicator that different levels of learning were involved. We particularly see the emergence of the teacher's personal voice as the utmost indicator of her new professional understanding of language education in pre-school years, which ended up being of her own and for herself. For these reasons we affirm that hers is a robust learning. We take this as strong evidence of the role of guided reflection through portfolio writing in in-service learning contexts. By highlighting the growth achieved, this case study also corroborates the teacher's professional needs as far as language education is concerned, at the same time as allowing us to refine central tenets of reflective learning theory itself, such as dimensions involved in reflective learning (theory, practice, and practitioner), the complex role that theory plays in such learning, and the experience of different personal stances in the learning process.

We believe that the growth the teacher underwent was powerfully supported by the guided writing process and the decision to focus on this case for analysis was initially based on the fact that this teacher accepted our guidelines and suggestions. We also believe that the analysis revealed the new knowledge, active experiencing, and self-assessment that this teacher built by so doing. We assume that the space created by the guided portfolio writing was the 'stage' in which deliberate thinking about herself as a practitioner, done with the aim of improving her understanding and practices, was performed and the learning made tangible. As such, our findings bring empirical support to the role that is theoretically attributed to guided writing in teachers' professional development. In fact, we found this to be an exemplary case concerning the effectiveness of guided portfolio writing in the construction of reflective learning in in-service contexts, thereby allowing us to find an answer to the main question that prompted this inquiry.

We are not contending, however, that the guided dimension of the writing process was the only determining factor of the teacher's learning. Indeed other factors seem to have intervened. Firstly, the preliminary reflections reveal this teacher's pedagogical maturity: the initial reports are carefully constructed, showing genuine concern for children's learning. Secondly, the teacher apparently possessed a strong predisposition to learn reflectively, which the guidelines seemed to have enhanced. She understood the relevance of the guidelines and allowed herself to be guided by them: she did not refrain from confronting herself openly, which many others did. In effect, we have observed many other portfolios that show how other teachers did not take advantage of the guidelines in the same proficient way. The hypothesis comes to our minds that such teachers might not in fact understand the meaning of reflective learning at all. Reflective learning is a relatively recent concept in the Portuguese educational scenario and, despite the focus put on reflective learning by the current in-service legislation, older teachers may not have in fact grasped its meaning and implications. Further research is now needed to understand this situation 
more closely. Finally, although this case clearly evidences how the guided portfolio becomes a stage for scaffolding individual learning, there was, during this in-service learning, a broader professional community scaffolding beyond and behind that as well, which we were unable to capture for analysis.

\section{Conclusions}

We have reached two important conclusions. One concerns the effectiveness of scaffolding reflective learning through guided portfolio writing in in-service learning contexts. The case study contributed to our understanding of the potential offered by guided portfolio writing as a scaffold for reflective learning in in-service learning contexts. We believe that our guidelines helped the teacher to reach a Zone of Proximal Development (Vygotsky 1986).

The other conclusion concerns the very conception of scaffolding in in-service learning contexts, indeed relevant to our understanding of the decisive role played by language as an inescapable mediating tool. Portfolio writing was clearly done with a complex pedagogical intent, which was the transformation and enhancement of the teacher's lived experience, and the pre-school teacher who went through the process of learning through reflective writing was the main witness and beneficiary of the renewed meanings that she actually built (Darling 2001). Yet the idea comes strongly to mind of how important it might have been for all the teacher participants in our in-service program to have had the opportunity to get acquainted with such an illustrative and illuminating case of what it means to learn reflectively (Stake 2000). We strongly believe that others could have better understood the meaning of reflective learning and the dynamics of the learning process before they themselves had started their own learning path. By providing written samples of reflective learning, as proposed by Shulman $(1986,1992)$ or discussed by Darling-Hammond and Hammerness (2002), we could have assisted them to distinguish and recognize levels of reflection, enlightening them as to how to engage in the reflective process, in spite of the risk of encouraging writing to please or restraining creativity. Put simply: although we believe in the importance of the role of scaffolding reflection through writing in in-service learning contexts, we have also concluded that scaffolding can be conceived of as a way of going further beyond providing guidelines to include the familiarization and study of exemplary cases of situated written reflective learning. By instantiating the potential of the practice of writing and model reflective thinking for teachers themselves, we would be helping them 'to think like a teacher' (Shulman 1992, 1). We are now willing to do that on future in-service learning occasions for teachers.

\section{Disclosure statement}

No potential conflict of interest was reported by the authors.

\section{Funding}

This work was supported at the Universidade do Minho by national funds provided by Fundação para a Ciência e a Tecnologia (FCT), Portugal. The first author was funded by [grant PEst-OE/CED/UI1661/2011] through CIEd (Centro de Estudos em Educação). The second and third authors were funded by [grant PEst-OE/CED/UI0317/2014] through CIEC (Centro de Investigação em Estudos da Criança). 


\section{Notes}

1. The research was conducted at the Instituto da Educação of Universidade do Minho.

2. All excerpts have been translated from Portuguese.

\section{Notes on contributors}

Íris Susana Pires Pereira, $\mathrm{PhD}$, is an assistant professor of language and literacy education at the Institute of Education, University of Minho. Her research focuses on language and literacy learning in the early years as well as on teachers' professional development. Recently, she has also added digital literacy to her research interests and she is currently a National Representative of the COST Action: The Digital Literacy and Multimodal Practices of Young Children (DigiLitEY).

Maria Cristina Cristo Parente received her $\mathrm{PhD}$ degree in Childhood Education, area of specialization: Methodology of Childhood Education and Supervision. She is an assistant professor of early childhood education at the Institute of Education, University of Minho, and she is a researcher at CIEC (Research Centre on Child Studies) at the University of Minho. Her research focuses on training and professional development of educators and teachers, childhood pedagogy and pedagogical supervision, assessment in childhood education and teacher leadership.

Cristina Vieira da Silva received her PhD degree in Linguistics in 2003. Since then, she has worked as a coordinator professor at the Higher School of Education of Paula Frassinetti, in Oporto, Portugal and she is a researcher at CIEC (Research Centre on Child Studies) at the University of Minho. Her areas of research are language teaching and learning, literacy education, reading and grammar teaching.

\section{References}

Anderson, Rebecca, and Lisa De Meulle. 1998. "Portfolio Use in Twenty-four Teacher Education Programs." Teacher Education Quartely 25 (1): 23-31.

Bazerman, Charles. 2009. "Genre and Cognitive Development: Beyond Writing to Learn." In Genre in a Changing World. Perspectives on Writing, edited by Charles Bazerman, Adair Bonini, and Débora Figueiredo, 279-294. WAC Clearinghouse and Parlor Press http:// wac.colostate.edu/books/genre/.

Bazerman, Charles, Kelly Simon, Patrick Ewing, and Patrick Pieng. 2013. "Domain-specific Cognitive Development through Writing Tasks in a Teacher Education Program." Pragmatics \& Cognition 21 (3): 530-551.

Berril, Deborah, and Emily Addison. 2010. "Repertoires of Practice: Re-framing Teaching Portfolios." Teaching and Teacher Education 26 (5): 1178-1185.

Britton, James. 1970. Language and Learning. London: Penguin Books.

Broekman, Harrie, and Heather Scott. 2006. "Teacher Development by Using Writing as a Tool." Teacher Development 3 (2): 233-248.

Bruffee, Kenneth. 1986. "Social Construction, Language, and the Authority of Knowledge: A Bibliographical Essay." College English 48 (8): 773-790.

Cochran-Smith, Marilyn, and Susan Lytle. 1993. Inside/outside Teacher Research and Knowledge. New York: Teachers College Press.

Darling, Linda Farr. 2001. "Portfolio as Practice: The Narratives of Emerging Teachers." Teaching and Teacher Education 17 (1): 107-121.

Darling-Hammond, Linda, and Karen Hammerness. 2002. "Toward a Pedagogy of Cases in Teacher Education.” Teaching Education 13 (2): 125-135.

Day, Christopher. 1993. "Reflection: A Necessary but Not Sufficient Condition for Professional Development." British Educational Research Journal 19 (1): 83-93.

Day, Christopher. 1999. Developing Teachers. The Challenges of Lifelong Learning. London: Falmer Press.

Delandshere, Ginette, and Sheila Arens. 2003. "Examining the Quality of the Evidence in Preservice Teacher Portfolios." Journal of Teacher Education 54 (1): 57-73. 
Dewey, John. 1916. Democracy and Education. New York: MacMillan Publishing.

Dewey, John. 1938. Experience and Education. New York: Collier Books.

Dionísio, Maria Lourdes, and Íris Susana Pires Pereira. 2006. "A educação pré-escolar em Portugal: concepções oficiais, investigação e práticas" [Pre-school Education in Portugal: Official Conceptions, Research and Practice]. Perspectiva 24 (2): 569-596.

Doecke, Brenton. 2013. "Storytelling and Professional Learning." English in Australia 48 (2): $11-21$.

Doecke, Brenton, and Íris Susana Pires Pereira. 2012. "Language, Experience and Professional Learning (What Walter Benjamin Can Teach Us)." Changing English 19 (3): 269281.

Eisner, Elliot. 1982. Cognition and Curriculum. A Basis for Deciding What to Teach. New York: Longman.

Eisner, Elliot. 2006. Reimagining Schools. The Selected Works of Elliot W. Eisner. London: Routledge.

Elliott, John. 1991. Action Research for Educational Change. Philadelphia: Open University Press.

Hatton, Neville, and David Smith. 1995. "Reflection in Teacher Education: Towards Definition and Implementation." Teaching \& Teacher Education 11 (1): 33-49.

Imhof, Margaret, and Christine Picard. 2009. "Views on Using Portfolio in Teacher Education." Teaching \& Teacher Education 25 (1): 149-154.

Katz, Lilian, Joaquim Ruivo, Isabel Silva, and Teresa Vasconcelos. 1998. Qualidade e Projecto na educação pré-escolar [Quality and Project in Pre-school Education]. Lisbon: Ministério da Educação/Departamento de Educação Básica/Núcleo de Educação Pré-Escolar.

Kemmis, Stephen, and Robin McTaggart. 1987. The Action Research Planner. Waurn Ponds: Deakin University Press.

Korthagen, Fred, and Angelo Vasalos. 2005. "Levels in Reflection: Core Reflection as a Means to Enhance Professional Growth." Teachers and Teaching: Theory and Practice 11 (1): 47-71.

Lave, Jean, and Etienne Wenger. 1991. Situated Learning. Cambridge: Cambridge University Press.

Lopes, João, and Paulo Fernandes. 2009. "Emergent Literacy Beliefs in Pre-school and Kindergarten Contexts." L1 Educational Studies in Language and Literature 9 (4): 5-26.

Marcos, Juan Jose, Emilio Sanchez Miguel, and Harm Tillema. 2009. "Teacher Reflection on Action: What is Said (in Research) and What is Done (in Teaching)." Reflective Practice 10 (2): 191-204.

Miles, Matthew, and Michael Huberman. 1994. Qualitative Data Analysis. London: Sage.

Moon, Jennifer. 2004. A Handbook of Reflective and Experiential Learning. Theory and Practice. Abingdon: RoutledgeFalmer.

OECD. 2000. Early Childhood Education and Care Policy in Portugal, OECD Country Note. Paris: OCDE. http://www.oecd.org/dataoecd/60/36/34400146.pdf

OECD. 2001. Starting Strong: Early Childhood Education and Care. Education and Skill. Paris: OECD Publishing.

OECD. 2006. Starting Strong II: Childhood Education and Care. Paris: OECD Publishing.

Orland-Barak, Lily, and Hayuta Yinon. 2007. "When Theory Meets Practice: What Student Teachers Learn from Guided Reflection on Their Own Classroom Discourse." Teaching and Teacher Education 23 (6): 957-969.

Pereira, Íris Susana Pires, ed. 2010. O ensino do português no $1 .{ }^{\circ}$ ciclo do ensino básico. Construção de saberes profissionais no contexto do PNEP e do novo programa de português, 2 Volumes [Teaching Portuguese in the First Cycle of Basic Education. Building Professional Knowledge in the Context of PNEP and the New Portuguese Curriculum, 2 Volumes]. Braga: Instituto de Educação da Universidade do Minho - Serviço de Publicações.

Pereira, Íris Susana Pires. 2012. "Language Education in the Pre-school Years: Learning about Teachers' Learning through an In-service Program." The Inescapability of Language. Theory and Practice for L1 Educators. Special Issue of L1 Educational Studies on Language and Literature 12: 1-23. 
Pereira, Íris Susana Pires. 2014. "Writing and the Situated Construction of Teachers' Cognition: Portfolios as Complex Performative Spaces." Language and Education 28 (6): 521-538.

Perret, Gillian. 2003. "Teacher Development through Action Research. A Case Study in Focused Action Research." Australian Journal of Teacher Education 27 (2): 1-10.

Rosen, Harold. 1987. Stories and Meanings. Sheffield: National Association for the Teaching of English.

Sá-Chaves, Idália. 2009. Portefólios Reflexivos. Estratégia De Formação E Supervisão [Reflexive Portfolios. Training and Supervision Strategy]. Aveiro: Universidade de Aveiro.

Schön, Donald. 1983. The Reflective Practitioner: How Professionals Think in Action. New York: Basic Books.

Shulman, Lee. 1986. "Those Who Understand: Knowledge Growth in Teaching." Educational Researcher 15 (2): 4-14.

Shulman, Lee. 1992. "Toward a Pedagogy of Cases." In Case Method in Teacher Education, edited by Judith H. Shulman, 1-30. New York: Teachers College Press.

Shulman, Lee. 1998. "Teacher Portfolios: A Theoretical Activity." In With Portfolio in Hand: Validating the New Teacher Professionalism, edited by Nona Lyons, 23-37. New York: Teachers College Press.

Silva, Ana Maria. 2000. "A formação contínua de professores: Uma reflexão sobre as práticas e as práticas de reflexão em formação" [In-service Teacher Training: A Reflection on the In-service Practices and Reflection Practices]. Educação \& Sociedade XXI (72): 89-109.

Stake, Robert. 2000. "Case Studies." In Handbook on Qualitative Studies, edited by Norman Denzin and Yvonna Lincoln, 435-454. Thousand Oaks: Sage.

Swales, John. 1988. "Discourse Communities, Genres and English as an International Language." World Englishes 7 (2): 211-220.

Taguchi, Hillevi Lenz. 2010. Going beyond the Theory/Practice Divide in Early Childhood Education: Introducing an Intra-active Pedagogy. London: Routledge.

Van Manen, Max. 1989. "Pedagogical Text as Method: Phenomenological Research as Writing." Saybrook Review 7 (2): 23-45.

Van Manen, Max. 1990. Researching Lived Experience. Human Science for an Action Sensitive Pedagogy. New York: The New York Press.

Van Manen, Max. 2006. "Writing Qualitatively, or the Demands of Writing." Qualitative Health Research 16 (5): 713-722.

Vasconcelos, Teresa. 2006. "Educação de infância e promoção da coesão social" [Early Childhood Education and the promotion of social cohesion]. In Relatório do Estudo. A educação das crianças dos 0 aos 12 anos, edited by Isabel Alarcão, 141-175. Lisbon: Conselho Nacional de Educação.

Vieira, Flávia. 2006. "Para a compreensão do portefólio de aprendizagem" [Understanding the Learning Portfolio]. In Actas do $1^{\circ}$ Encontro sobre e-Portefólio/Aprendizagem Formal e Informal, edited by Lia Raquel Oliveira and Maria Palmira Alves, 7-14. Oliveira de Azeméis: Ludomedia.

Vygotsky, Lev. 1986. Thought and Language. Cambridge, MA: MIT Press.

Wells, Gordon. 1999. Dialogic Inquiry. Cambridge: Cambridge University Press.

Wolf, Kenneth, and Yvonne Siu-Runyan. 1996. "Portfolio Purposes and Possibilities." Journal of Adolescent \& Adult Literacy 40 (1): 30-37.

Zeichner, Kenneth, and Daniel Liston. 1996. Reflective Learning: An Introduction. Mahwah: Lawrence Erlbaum Associates.

Zeichner, Kenneth, and Susan Wray. 2001. "The Teaching Portfolio in US Teacher Education Programs: What We Know and What We Need to Know." Teaching and Teacher Education 17 (5): 613-621. 